\title{
Digitally Produced Judgements in Modern Court Proceedings
}

\author{
H.W.R. (Henriëtte) Nakad-Weststrate \\ Founder and Director of e-Court \\ Moersbergselaan, \\ The Netherlands
}

\author{
H.J. (Jaap) van den Herik \\ Centre for Law in the Information Society \\ Leiden University, The Netherlands
}

\author{
A.W. (Ton) Jongbloed \\ Faculty Law, Economics, Government and \\ Organization \\ Molengraaff Institute for Civil Law \\ Utrecht University, The Netherlands
}

\begin{abstract}
This paper shows an improvement of legal decision-making via digitally produced verdicts. We investigate the use of Artificial Intelligence (AI) in relation to rendering arbitrational verdicts. The data was provided by e-Court, the first private online court of the Netherlands. In our survey the standard debt collection proceedings under Dutch Civil and Procedural law are used as a case study. The introduction of the subject matter is followed by an overview of the key-parameters required by e-Court for rendering a verdict in default cases. The reasoning methodologies of Intelligent Systems in the legal domain are then discussed. Following this discussion, we will analyze the nature of the e-Court System to understand how it benefits from the various types of Intelligent Systems. Subsequently, we will discuss the rationale behind the choices made, the legal implications and the handling process within the public courts. We review in brief some expectations about the further developments and compare them with the current best practices at the Dutch e-Court. Our contribution lies also in the investigation of the characteristics of the e-Court system for rendering default verdicts in debt collection proceedings. In our conclusion we will consider to what extent intelligent systems will be used in the contemporary digital court houses.
\end{abstract}

\section{Introduction}

Private court proceedings have played an important role throughout the centuries. As far back as in ancient Egypt there are recordings of arbitration by private courts. The proceedings, which are quite similar to contemporary arbitration, were elaborated by Pharaoh Chephren (26th century B.C.), also known for the second pyramid of Giza [1], [2].

In contrast, we deal with digital private court proceedings. They are a recent phenomenon. A quarter of a century ago. (June $21^{\text {st }}, 1991$ ) Jaap van den Herik shocked his audience in his inaugural lecture by addressing the question: "Can computers judge court cases?". He even wondered whether robotic judges might be better at it than (human) judges ever would be [3]. A second question was whether computers eventually would deliver such judgments. In one of the final paragraphs, with the title: "2984?", he stated: "On the basis of these conclusions and beliefs I speculate with you on the future. I will not write science fiction, but rather I want to invoke you to think with me about a future in which the tribunal of reason will be supplemented or supported by tribunals of computers".

Albeit sooner than expected, his vision became a reality. Within 20 years, on January $11^{\text {th }}, 2010$ the first online private court in the Netherlands was launched [4 - 10]. It was the first court which offered fully digitalized court proceedings. Several earlier attempts by the Dutch State, between the late 1980's and 2010, to establish digital public court proceedings had all failed without exception [11-14]. In relation to cases endowed with arguments pro and con, the e-Court verdicts are indeed the result of human reasoning, supported to a large degree by specifically designed software, as forecasted in 1991.

Yet, it did not end there and then. Let us see what happened. Since early 2011, one specific type of verdicts - the e-Court judgments by default in debt collection proceedings - are no longer the product of any human reasoning; the verdicts are rendered as the sole result of AI. Although we may have in mind that the so-called 'robotic' or 'digital' judge has been in office for a number of years whilst going unnoticed, its appearance in an actual court can be considered a silent revolution in the legal court system.

In our opinion the rise of the robotic judge is a unique development to be distinguished from other developments of our time, such as Crowdsourced Online Dispute Resolution (CODR). To support our opinion, we provide a small description. For our definition of the term CODR, we start by using the definition of ODR as provided by Kaufmann-Kohler and Schultz [15]. ODR is "a broad term that 
encompasses forms of Alternative Dispute Resolution (ADR) and court proceedings which use internet as a part of the dispute resolution process" [15]. As to the " $C$ " in CODR it refers to "the Crowd". Crowd sourcing has attracted great interest in the academic world, in Europe notably since 2010 and it is even perceived to dominate the future of online dispute resolution [15-26]. Yet, the use of AI functioning on a stand-alone basis, instead of by human reasoning, appears even today a topic of science fiction, and in the opinion of many legal professionals a frightening and undesirable future.

In this paper we will set out the relevant key parameters to allow a digital judge to render a verdict by default in arbitration proceedings at e-Court. Then we will focus on the reasoning methodologies for intelligent systems. As a case in point we will investigate a case-study with the following three elements: (i) the Plaintiff is a company, (ii) the Defendant is a consumer, and (iii) the claim amount is a small monetary claim in the domain of debt collection (an unpaid invoice with a maximum of $€ 1,500)$.

\section{Key Parameters for rendering a verdict}

We consider three different areas: the claim (in 2.1.), the costs of debt collection (in 2.2.) and the course of the proceedings (in 2.3.). For each area, there are two classes of key parameters for legal decision making in the sense of rendering a verdict, viz. for (i) the required data, and (ii) the restrictive rules in relation to the use of these data. The relevant required data are to be found for the large part in article 1057 Dutch Code of Civil Proceedings, and article 96, Book 6 Dutch Civil Code. The rules and restrictions follow from the Code of Civil Proceedings, the Civil Code as well as from jurisprudence.

\subsection{Parameters regarding the claim}

Regarding the claim, the following data are required for rendering a verdict.

- Claim amount

- Due Date of the claim amount

- Interest over the claim amount

- Interest date

- Full legal names, birth dates and addresses of the Parties

There are a at least four restrictive rules in relation to the use of these data.

The first rule is that the contractual basis from which the claim occurred must be clear.

The second rule is that in spite of a Due date of an invoice, the Plaintiff must have sent at least one reminder and a minimum of two collection letters to the Defendant in order for the debt to be payable by a consumer.

The third rule has a relation to the interest. The interest date has to be determined, as well as the percentage of the interest and the proportionality with regard to the claim amount.

The fourth rule is that the calculation of the interest, and other costs (see below, under B) may be affected by the claim amount. Therefore, if the judge does not award the full claim amount as presented by the Plaintiff, the other amounts will be recalculated.

\subsection{Parameters regarding the costs of debt collection}

Regarding the costs of debt collection, the following data are required for rendering a verdict:

- Costs of debt collection (made in advance).

- Costs of the writ of summons in which the court proceedings are announced.

- Court fee (private court).

- Court fee (public court, to make the binding private verdict enforceable).

- Costs of representation in court.

There are at least five restrictive rules in relation to the use of these data.

The first rule is that the cost of debt collection made in advance are limited pursuant to the law.

The second rule is that these costs cannot be claimed, unless the Plaintiff has sent at least one reminder and a minimum of two collection letters to the Defendant in order for the debt to be payable by a consumer.

The third rule is that the cost of the writ of summons are determined by legislation.

The fourth rule relates to the Court fee. The Court fee consists of two elements: (1) the costs of arbitration, which are determined by the private court, and (2) the costs of the public courts to allow execution of the arbitrational verdict. Limitations in relation to these costs are found in jurisprudence from the Supreme Court (i.e., verdicts by the Supreme Court). They show that private court proceedings can be considered "unfair" vis-à-vis consumers, if the total costs of the private court exceed the total costs of the public courts for similar cases.

The fifth rule relates to the costs of representation in court. These costs can vary per lawyer. In the Dutch legal system, a party can usually only receive a predetermined fixed amount as compensation for the costs. In many legal proceedings this amount is merely a modest contribution in the lawyer's and court fees. 


\subsection{Parameters regarding the course of the proceedings}

Regarding the costs of debt collection, the following data are required for rendering a verdict.

- Is the court competent for rendering a verdict in this specific dispute, based on a contract between the parties?

- Was the Defendant duly notified of the oncoming court proceedings by issuing a writ of summons?

- Did the Defendant exercise his right to invoke the competence of the public court for this specific dispute during the four weeks following the writ of summons?

- Were the proceedings held in accordance with the court's Arbitration Rules?

- Did the Defendant appear in court or was he in default?

- Should the claim nevertheless be rejected because of unlawfulness or unreasonableness?

A number of the six parameters can pose a problem, depending on the factual outcome of the stated question.

For example, if the parties have no contractual clause appointing the private court, the court is not competent and therefore cannot pass a judgment. If the Defendant was not duly notified, the court cannot pass judgment. These parameters are therefore of a "fact finding" nature.

\section{Reasoning Methodologies of ISs}

From the knowledge engineering point of view, the main two components in developing an efficient and robust Intelligent System in any domain are (i) the knowledge base and (ii) the inference engines [27-32].

Ad (i) Concerning the knowledge base there are many knowledge representations and management techniques, e.g. lists, trees, semantic networks, frames, scripts, production rules, cases, and ontologies. The key to the success of such systems is the selection of the appropriate techniques that best fit the domain knowledge and the problem to be solved. The choice depends on the experience of the knowledge engineer.

Ad (ii) Regarding the inference engine, there are many methodologies and approaches of reasoning, e.g., automated reasoning, case-based reasoning, commonsense reasoning, fuzzy reasoning, geometric reasoning, non-monotonic reasoning, model-based reasoning, probabilistic reasoning, causal reasoning, qualitative reasoning, spatial reasoning and temporal reasoning. In fact, these methodologies receive increasing attention within the AI in law and legal information processing.
Below, we will briefly analyze three distinguished types of Intelligent Systems in the legal domain, previously denoted as Expert Systems. We list Legal Rule-Based Systems (in 3.1.), Frames and Semantic Networks (in 3.2.), and Case-Based Systems (in 3.3.). We will then bring this section to a close (in 3.4.) with a discussion of the use of these Intelligent Systems in relation to the nature of the eCourt system for debt collection proceedings.

\subsection{Survey of Rule-Based Systems}

Rule-based systems solve problems by taking an input specification and then "chaining" together the appropriate set of rules from the rule base to arrive at a (new) solution. Given the same exact problem situation, the system will go through exactly the same amount of work and arrive at the new solution. In other words, rule-based systems do not inherently learn. In addition, given a problem that is outside the system's original scope, the system often cannot render any assistance. Moreover, Rule-Based Systems are quite time-consuming to build and maintain. The main reason is that rule extraction from experts is labor-intensive and rules are inherently dependent on other rules, making the addition of new knowledge to the system a complex debugging task [33-35].

Table 1 shows five historic examples of RuleBased Systems for particular legal tasks to show that earlier ideas are now coming to fruition.

Table 1. Examples of Rule-Based Systems for particular legal tasks

\begin{tabular}{|l|l|l|l|}
\hline \multirow{2}{*}{ System } & \multicolumn{3}{|c|}{ Examples of Rule-Based Systems for particular legal } \\
tasks
\end{tabular}

\subsection{Survey of Frames and Semantic Nets}

Semantic networks are basically graphical depictions of knowledge that show hierarchical 
relationships between objects. A semantic network is made up of a number of nodes, which represent objects and descriptive information about those objects. Objects can be any physical items such as a book, car, desk, or even a person. Nodes can also be concepts, events, or actions. The nodes in a semantic network are also interconnected by link or arcs. The arcs show the relationships between the various objects and descriptive factors. Some of the most common arcs are of the is-a or has-a type [36-41].

Nowadays, two developments have been instrumental to let the networks grow to powerful representative networks. The developments are (i) High Performance Computing ('HPC') and (ii) adequately handling Big Data. The main technique which has been made possible owing to HPC, is machine learning [42]. In relation to adequately handling Big Data we nowadays rely on Deep Learning [43]. Deep Learning is able to find connections at a very deep level between items which cannot be discovered on earlier levels [44].

Table II shows again five historic examples of Frames and Semantic Nets in the domains of legal reasoning and argumentation. In fact, they contain the ideas which are now effective in the new environment of HPC and Big Data in combination with Deep Learning.

Table 2. Examples of Frames and Semantic Nets in legal reasoning and argumentation

\begin{tabular}{|c|c|c|c|}
\hline \multirow[b]{2}{*}{ System } & \multicolumn{3}{|c|}{$\begin{array}{l}\text { Examples of Frames and Semantic Nets in legal } \\
\text { reasoning and argumentation }\end{array}$} \\
\hline & Task & $\begin{array}{l}\text { Developing } \\
\text { Tools/K.R. } \\
\text { Technique }\end{array}$ & Site \\
\hline JUDITH & $\begin{array}{l}\text { Helps lawyers reason } \\
\text { about civil law cases }\end{array}$ & $\begin{array}{l}\text { FORTRAN/ } \\
\text { Relationship } \\
\mathrm{s}\end{array}$ & $\begin{array}{l}\text { Universities } \\
\text { of Heidelberg } \\
\text { and } \\
\text { Darmstadt }\end{array}$ \\
\hline $\begin{array}{l}\text { LAS (Legal } \\
\text { Analysis } \\
\text { System) }\end{array}$ & $\begin{array}{l}\text { Helps lawyers perform } \\
\text { simple legal analyses } \\
\text { about the international } \\
\text { torts of assault \& } \\
\text { battery }\end{array}$ & $\begin{array}{l}\text { PSL/ } \\
\text { Semantic } \\
\text { Net }\end{array}$ & MIT \\
\hline $\begin{array}{l}\text { LRS (Legal } \\
\text { Research } \\
\text { System) }\end{array}$ & $\begin{array}{l}\text { Helps lawyers retrieve } \\
\text { information about court } \\
\text { decisions \& legislation } \\
\text { in the domain of } \\
\text { negotiable instrument } \\
\text { law, an area of } \\
\text { commissioner law that } \\
\text { deals with checks \& } \\
\text { promissory notes }\end{array}$ & $\begin{array}{l}\text { Knowledge } \\
\text { Base/ } \\
\text { Semantic } \\
\text { Net }\end{array}$ & $\begin{array}{l}\text { University of } \\
\text { Michigan }\end{array}$ \\
\hline SARA & $\begin{array}{l}\text { Helps lawyers analyze } \\
\text { decisions governed by } \\
\text { discretionary norms }\end{array}$ & $\begin{array}{l}\text { Statistical } \\
\text { Tool/ } \\
\text { Frames }\end{array}$ & ROSIE \\
\hline TAXMAN & $\begin{array}{l}\text { Assists in the } \\
\text { investigation of legal } \\
\text { reasoning and legal } \\
\text { argumentation using } \\
\text { the domain of corporate } \\
\text { tax law }\end{array}$ & $\begin{array}{l}\text { AIMDS/ } \\
\text { Frames }\end{array}$ & EMYCIN \\
\hline
\end{tabular}

\subsection{Survey of the Case-Based Systems}

From a knowledge engineering point of view, a case is a list of features that lead to a particular outcome (e.g., the information on a legal argument and the associated evidences). A complex case is a connected set of sub cases that form the problem solving task's structure. Determining the appropriate case features is the main knowledge engineering task in case-based systems. This task involves defining the terminology of the domain and gathering representative cases of problem solving by the expert knowledge engineer. Case-Based reasoning (CBR) is an analogical reasoning method which provides both a methodology for problem solving and a cognitive model of people.

CBR means reasoning from experiences or "old cases" in an effort to solve problems, to give critique on proposed solutions, and explain anomalous situations. It is consistent with observations that psychologists have made in the natural problem solving practice. It is similar to what people do. People tend to be comfortably using the CBR methodology for decision making, in dynamically changing situations and other situations where much is unknown and where solutions are not clear.

CBR refers to a number of concepts and techniques that can be used to record and index cases and then search them to identify the ones that might be useful in solving new cases when they are presented (here Deep Learning occurs to be the main driver). In addition, there are techniques that can be used to modify earlier cases to better match new cases and other techniques to synthesize new cases when they are needed [45-48].

From the knowledge engineering point of view, one can summarize the CBR methodology in the following six processes.

1. Assign Indexes: where the features of the new case are assigned as indexes characterizing the event.

2. Retrieve: where the indexes are used to retrieve a similar past case from the case memory (the past case contains the prior solution).

3. Modify: where the old solution is modified to conform to the new situation, resulting in a proposed solution.

4. Test: where the proposed solution is tried out. It either succeeds or fails.

5. Assign and Store: If the solution succeeds, then assign indexes and stores a working solution. The successful plan is then incorporated into the case memory.

6. Explain, Repair and Test: If the solution fails, then explain the failure, repair the working solution, and test again. The explanation process identifies the source of the problem. The predictive features of the problem are incorporated into the indexing rules knowledge structure to anticipate this problem in the future. The failed plan is repaired to fix the problem, and the revised solution is then tested. 
The idea of CBR is becoming popular in developing knowledge-based systems because it automates applications that are based on precedent or that contain incomplete causal models. In a rulebased system an incomplete mode or an environment which does not take into account all variables could result in either an answer built on incomplete data or simply no answer at all. The CBR methodology attempts to get around this shortcoming by inputting and analyzing problem data.

Table 3 shows seven again historical examples of Case-Based Systems in the legal domain. They have made the advancement to the current developments possible.

Table 3. Examples of case-based systems in the legal domain

\begin{tabular}{|c|c|c|c|}
\hline \multirow[b]{2}{*}{ System } & \multicolumn{3}{|c|}{ Examples of Case-Based Systems in the legal domain } \\
\hline & Task & $\begin{array}{c}\text { Developing } \\
\text { Tools }\end{array}$ & $\begin{array}{l}\text { Rule-Based } \\
\text { Systems Site }\end{array}$ \\
\hline HYPO & $\begin{array}{l}\text { Performs modeling legal } \\
\text { argument and adversarial } \\
\text { reasoning with cases and } \\
\text { hypotheticals in the legal } \\
\text { domain }\end{array}$ & CBR Tool & \\
\hline LIR & $\begin{array}{l}\text { Performs retrieval of legal } \\
\text { documents }\end{array}$ & CBR Tool & \\
\hline Bank XX & $\begin{array}{l}\text { Case-Based legal } \\
\text { argument system that } \\
\text { retrieves cases and other } \\
\text { legal knowledge pertinent } \\
\text { to a legal argument } \\
\text { through a combination of } \\
\text { heuristic search and } \\
\text { knowledge-based } \\
\text { indexing }\end{array}$ & CBR Tool & \\
\hline FLES & $\begin{array}{l}\text { Supports the law students } \\
\text { in studying the vague } \\
\text { concepts in the contracts } \\
\text { for the international Sale } \\
\text { of Goods. It explains what } \\
\text { the meaning of vague } \\
\text { legal concept in a query } \\
\text { case is }\end{array}$ & CBR Tool & $\begin{array}{l}\text { Tokyo Institute } \\
\text { of Technology }\end{array}$ \\
\hline $\begin{array}{l}\text { LAW- } \\
\text { CLERK }\end{array}$ & Cross-context reminding & CBR Tool & $\begin{array}{l}\text { University of } \\
\text { Connecticut }\end{array}$ \\
\hline GREBE & $\begin{array}{l}\text { Exemplar-based } \\
\text { Explanation }\end{array}$ & CBR Tool & $\begin{array}{l}\text { University of } \\
\text { Texas }\end{array}$ \\
\hline JUDGE & $\begin{array}{l}\text { Applies the case-based } \\
\text { approach to legal } \\
\text { reasoning in the context } \\
\text { of sentencing convicted } \\
\text { criminals }\end{array}$ & CBR Tool & \\
\hline
\end{tabular}

\subsection{The nature of the e-Court System for Debt Collection Proceedings}

We will now analyze the e-Court System in order to understand the nature of this system and to assess under which type of the Intelligent Systems it can be categorized.

In order to make such an assessment, we have developed a table with an overview of the key tasks in debt collection proceedings under Dutch law. We translate these tasks into system requirements.

Finally, we analyze what type of Intelligent System is used in the relevant system.
Table 4 shows the seven characteristics of the eCourt System for rendering default verdicts in debt collection proceedings. They are:

1. Identification of parties.

2. Establishing competence of the court

3. Establishing the correct application of the Court's procedural laws

4. Selection of the correct template

5. Deciding upon the correct verdict

6. Producing the original verdict (with the correct digital signature)

7. Determining that the claim is not unjust or unlawful

In Table 4 we add for each stage the system requirements (column 2) and the nature of the decision (column 3).

It is remarkable how straightforward the legal decisions in court cases are. In the seven stages (i.e., the characteristics of the e-Court System) we see only in the stages 4 and 5 the appropriate application of the techniques developed at the universities from the 1980's to 2010. Thirty years of intensive research is compressed into two (important) stages. And even there they play at this moment a subordinate role since the degree of hardness of the cases dealt with in e-Court is elementary when seen from a legal point of view.

Based on the information of Table IV we may draw three conclusions.

The first conclusion is that the e-Court System makes a limited use of the Rule Based systems, the Frames and Semantic Nets, and the Case-Based systems (see stages 4 and 5).

The second conclusion is that a number of tasks is performed on a pro-active, principle-based approach by Administrative Software (e.g., plain database requests), rather than on a reactive, case-bycase based approach using AI techniques.

The stages 1 to 3 are performed by Administrative Software only packed with at most a flavor of AI-techniques. The use of software packets indicates progress at the side of the lawyers (judges, plaintiffs and court bailiffs). So, in the regular human courts these three tasks are still performed by human intervention.

Task 4 and 5 are typical examples of tasks which in principle require AI techniques. In practice, i.e., the current world of Big Data, the modern means are involved in the following order of (1) Case Based Systems, (2) Rule Based Systems and (3) Semantic Networks. In fact, we see here the following: look first for the same or similar cases; if not found, then apply (simple) rules in the form of rule-based 
Table 4. Characteristics of the e-Court System for rendering Default Verdicts in Debt Collection Proceedings

\begin{tabular}{|c|c|c|}
\hline \multirow[b]{2}{*}{$\begin{array}{l}\text { Key Task in } \\
\text { Debt Collection } \\
\text { Proceedings } \\
\text { under Dutch } \\
\text { law }\end{array}$} & \multicolumn{2}{|c|}{$\begin{array}{l}\text { Characteristics of the e-Court System for rendering } \\
\text { Default Verdicts in Debt Collection Proceedings }\end{array}$} \\
\hline & System Requirements & $\begin{array}{l}\text { Nature } \\
\text { Rule-Based } \\
\text { Frames and } \\
\text { Semantic Nets / } \\
\text { Case Based / } \\
\text { External ES/ } \\
\text { /Human } \\
\text { Intervention }\end{array}$ \\
\hline $\begin{array}{l}\text { 1. Identify the } \\
\text { Parties, and } \\
\text { verify their data } \\
\text { (birth date, } \\
\text { address) }\end{array}$ & $\begin{array}{l}\text { Import the data from the } \\
\text { documents (contract, copy of } \\
\text { invoices) and verify the data } \\
\text { against the state's formal } \\
\text { registers. }\end{array}$ & $\begin{array}{l}\text { External ES (court } \\
\text { bailiff's) } / \text { /Human } \\
\text { Intervention (court } \\
\text { bailiffs) }\end{array}$ \\
\hline $\begin{array}{l}\text { 2. Establish } \\
\text { competence of } \\
\text { the court }\end{array}$ & $\begin{array}{l}\text { (a) Review the contract for a } \\
\text { forum choice; (b) Establish } \\
\text { that the Defendant (i) was duly } \\
\text { notified, (ii) did not use his } \\
\text { right to evoke competence of } \\
\text { the public court }\end{array}$ & $\begin{array}{l}\text { (a) Human } \\
\text { Intervention takes } \\
\text { place prior to the } \\
\text { admission of a } \\
\text { Plaintiff to the e- } \\
\text { Court system in a } \\
\text { principal, pro-active } \\
\text { manner rather than } \\
\text { in a reactive case- } \\
\text { by-case manner; } \\
\text { (bi) External ES } \\
\text { (court bailiff's } \\
\text { expert system, (bii) } \\
\text { External ES (court } \\
\text { bailiff's expert } \\
\text { system }\end{array}$ \\
\hline $\begin{array}{l}\text { 3. Establish that } \\
\text { the proceedings } \\
\text { were held in } \\
\text { accordance with } \\
\text { the court's } \\
\text { Arbitration } \\
\text { Rules }\end{array}$ & $\begin{array}{l}\text { E-Court System does not allow } \\
\text { to deviate from the Arbitration } \\
\text { Rules, and the Parties have } \\
\text { editing rights for claim/ } \\
\text { defense/ reaction/ final defense }\end{array}$ & Rule Based ES \\
\hline $\begin{array}{l}\text { 4. Select correct } \\
\text { template for a } \\
\text { Default Verdict }\end{array}$ & $\begin{array}{l}\text { In the absence of an uploaded } \\
\text { defense into the e-Court } \\
\text { system, the status of the case is } \\
\text { Default. The selection of the } \\
\text { template is linked to this status. }\end{array}$ & $\begin{array}{lll}\text { 1. } & \text { Case } & \text { Based } \\
\text { System } & \\
\text { 2. } & \text { Rule } & \text { Based } \\
\text { ESs } & \end{array}$ \\
\hline $\begin{array}{l}\text { 5. Award the } \\
\text { claimed amounts }\end{array}$ & $\begin{array}{l}\text { Due to the lack of defense the } \\
\text { claim is awarded fully }\end{array}$ & $\begin{array}{lll}\text { 1. } & \text { Case Based } \\
& \text { System } \\
\text { 2. } & \text { Rule Based } \\
& \text { ESs } \\
\text { 3. } & \text { Semantic } \\
& \text { Networks } \\
\end{array}$ \\
\hline $\begin{array}{l}\text { 6. Produce the } \\
\text { digitally signed } \\
\text { original, as well } \\
\text { as an unsigned } \\
\text { copy of the } \\
\text { completed } \\
\text { verdict }\end{array}$ & $\begin{array}{l}\text { Make the verdict available in } \\
\text { PDF, and allow for the original } \\
\text { document to be digitally } \\
\text { signed. }\end{array}$ & $\begin{array}{l}\text { Administrative } \\
\text { Software }\end{array}$ \\
\hline $\begin{array}{l}7 . \text { Determine } \\
\text { that the claim is } \\
\text { not unjust or } \\
\text { unlawful }\end{array}$ & & $\begin{array}{l}\text { Human Intervention } \\
\text { takes place prior to } \\
\text { the admission of a } \\
\text { Plaintiff to the e- } \\
\text { Court system in a } \\
\text { principal, pro-active } \\
\text { manner rather than } \\
\text { in a reactive case- } \\
\text { by-case manner }\end{array}$ \\
\hline
\end{tabular}

systems; if no verdict has been composed continue the work by reasoning in a semantic network.

The stages 6 and 7 are more elementary and can therefore be performed by Administrative Software. Of course, in a human court, it will be done in interaction between human beings and administrative programs.
We will explain the simplicity of the computer procedure by using an example in relation to the establishment by the judge whether or not the court is competent to render a verdict. Let us assume that a health insurance company in the Netherlands wishes to submit its debt collection cases to e-Court for handling it according to the existing legal ruling. The company indicates that there will be approximately 30,000 legal proceedings per annum. As to the first System Requirement, the digital judge will not have to make the assessment on a case by case basis. The assessment is made in an earlier stage, being the moment when e-Court decides whether or not to give the health insurance company access to the e-Court System. There is a plaintiff acceptance policy established, which is similar to the "know your customer" rules and regulations in the financial industry. One topic of investigation is a review of the standard contract used by the Plaintiff, in order to determine whether the standard contract contains a forum choice for e-Court. Following this due diligence of the future Plaintiff, which includes discussions in the field of consumer protection, the Plaintiff will or will not be accepted. This process is performed by human intervention, as e-Court prefers to establish a level of trust and would like be convinced of the integrity and the good faith of the Plaintiff.

The third conclusion is that the success of AI in the legal system will largely depend on (1) finding a well-considered path through a minefield consisting of the almost infinite number of technical possibilities, (2) the limited financial resources, and (3) the hindering complexity of the legislation, as well as (4) a legal conservative culture that enhances professional fear and mistrust of applying new ideas in practice.

A brief analysis results in the following. (1) finding a path will be perfectly performed by the current AI-programs, (2) the limited financial resources are advantageous for the computers, (3) the complexity of the law with respect to using computers is currently a real obstacle, and (4) the legal conservative culture among lawyers is the main obstacle for computer courts.

Following to point (3) and (4) above, the introduction of the first digital (i.e., non-human) judge in a legal environment as performed by eCourt had to be taken with utmost care. Hence, eCourt started resolving conflicts of a non-complex nature. Here it was soon revealed that even a simple software tool can evoke a huge impact on the legal system. The rationale behind the cautious policy is that a conservative approach of even a small step in technology can show the promise it entails. By doing so, e-Court has successfully averted the danger of falling into the trap of highly complicated, time consuming and expensive development processes that in the end would have resulted in a system far 
too sophisticated for the tasks ahead. The lessons learned over the past six years allow for further steps in the use of $\mathrm{AI}$ in legal decision making.

\section{The Rise of the Robotic Judge}

In view of the information provided, we acknowledge that there are many more benefits of the e-Court robotic judge in relation to our case study. We will restrict ourselves to a discussion of three (evident) benefits of the use of the digital judge (see 4.1.), followed by a presentation of one major legal complication (see 4.2.). We will then describe how the public courts currently process the verdicts and how they should be processed within five years (see 4.3.).

\subsection{Three benefits of the e-Court digital judge}

The first benefit is that the digital judge works fast. In today's world large numbers of well educated, well organized consumers participate in the economic and legal community. Since consumers purchase many goods and take even more services (with as implied consequence the emergence of many conflicts), the demand for justice has equally grown and now reached a scale that makes the use of ICT-tools a necessity.

The second benefit is that the digital judge can be considered the "most objective judge of the Netherlands", as the judge is impartial and will give rulings without favoring any of the parties involved on the basis of past or present relationships, misplaced empathy, admiration or other subjective influences in the decision making.

The third benefit is that the digital judge works without miscalculations. The software has been designed in such a manner, that all amounts are calculated without the risk of human error. (We disregard here, on purpose, the Volkswagen case.)

Finally, it is recalled with much emphasis that the benefits are based on handling conflicts of a noncomplex nature.

\subsection{The major legal complication}

There is one major legal complication in relation to the performance of the digital judge as seen from a legal point of view. Despite the benefits of using AI in decision making, Dutch legislation does not provide for the possibility of a digital judge. Its incorporation in the laws and regulations is not to be expected soon, although there is currently some reconsideration. The last fundamental modernization of the arbitration rules has just taken place, and the new arbitration law has come into effect as of January 1st, 2015. The solution to this problem required some legal engineering. The outcome thereof is the situation, whereby the digital judge renders the verdict in the name of the (human) judge. The task of the human judge is therefore limited to a random testing of the verdicts. To date, there has not been one case in which the human e-Court judge was able to improve the verdict by the digital judge.

\subsection{Handling the executional process by the public court}

Prior to the execution of an arbitrational verdict, one must still obtain a title for execution under Dutch law. These titles are listed in article 430 Dutch Code of Civil Proceedings. In relation to arbitrational verdicts the parties will usually seek permission for execution from the public court (article 1062 Dutch Code of Civil Proceedings). The procedure for obtaining the right of execution is as follows.

Since 2011, the original, digitally signed verdicts in PDF are sent to the public court, as an attachment (on a CD, USB or other data carrier) to a formal petition (on paper). The court will then print all verdicts on paper, and a court's clerk will manually insert the data, such as the names of the parties, the name of the (human) e-Court judge) in the public court's system. The clerks will then recalculate manually the awarded amounts (claim amount, interest rate, and other costs). This process is manually executed one verdict at a time.

To date, there has not been one case in which the clerks were able to improve the calculations in the verdict. However, there have been examples whereby human error occurred as a result of manual process of the clerks copying all data into the public court's system. We are curious to see how long this procedure would hold its position. We believe that within five years tables have been turned.

\section{The future of the digitally produced judgment}

In this paragraph we will briefly review two views (viz. by Susskind (see 5.1.) and Van den Herik (see 5.2.) relating to the expectations about the future digitalization in the legal domain. We complete the review by Richard and David Susskind's "The Future of the Profession" [49].

\subsection{The end of lawyers?}

The first view is taken from the book by Richard Susskind with the daring title "The End of Lawyers?" [50]. In our opinion this is an important pointer for those who have an interest in how the legal profession will evolve in the time ahead. It relates technology (especially the Internet), collaboration, globalization, and other forces. 
Obviously, they are changing the fundamental rules of providing legal services. The book contains several key observations about how the legal marketplace is being transformed. [51]

The central idea is the identification of an evolving and fluid spectrum of legal services categories: (i) bespoke (one-off, highly specialized and highly priced), (ii) standardized (drawing upon precedents, process or previous work), (iii) systematized (reduced and applied to automated systems), (iv) packaged (systematized services exported to clients) and (v) commoditized (packaged services so commonplace at a low price). Most lawyers and judges insisted until a few years ago that their practice consisted of rare and unique cases which eliminated any form of standardization, let alone that they could be commoditized.

In 2010 the senior author (HWN) of this article participated in the expert panel with Susskind (and others), on the occasion of a seminar on the commercial law practice in 2020, at the Dutch Nyenrode University. The discussion focused on the five above mentioned observations. The decomposition of legal tasks into component parts that can be delegated to various sources, was the main issue; only few of the actual law firm lawyers accepted this view. However, in our opinion, the developments offer tremendous opportunity for more efficient and effective legal services; we admit that they also represent major threats to various aspects of the traditional law firm business model. In fact, in the Netherlands we have already seen this development in practice in the debt collection industry. A part of the legal practice required the intervention of (specialized, highly priced) law firms until the late 1990's. After the turn of the century (1), lawyers played a much smaller role in the debt collection industry and (2) legal advisors of various sorts (paralegal offices, court bailiff organizations) took over. Software allowed for standardization and a systematic approach packaging and debt collection became a commodity.

In the same time in the Netherlands, Henriette Nakad-Weststrate had already evoked some debate defending the argument that e-Court was an example of the accuracy of Susskind's vision, as court proceedings had already developed from a luxury product into a commodity. One of the underlying assumptions widely supported is that one can recognize the quality of the work by the cost of the services. The advocates of this statement emphasize the human notion "speed equals lesser quality" due to the rush with which the work was done. Yet, they will soon learn that for computers the reverse is true.

\subsection{Judging court cases changes from a human activity to a computer based activity}

The second publication we review is the contribution by Jaap van den Herik and Jan Jaap Oerlemans to the Evening of Science and Society 2014 around the theme Blueprints of the future, today's science is tomorrow's world [52].

Their contribution was presented around the statement "Judging court cases is changing from a human activity to a computer based activity". In the article "Lawyers follow chess players" they noted that some lawyers seemed to have established as a fact that no single computer had ever been attributed the competence to adjudicate. Therefore, computers could never judge court cases. Other lawyers, who had an open mind to the notion as such, indicated that computers could never interpret correctly the vague norms and could never judge court cases for that reason. Still, almost all lawyers acknowledge that computer science facilitated the legal practice, and that data science will do even more so.

Van den Herik and Oerlemans simply stated that the judges will definitely follow the chess grandmasters. They are completely outperformed by the chess programs. There is no reason to assume that the world of lawyers is different from the world of chess grandmasters.

Next to Deep Blue beating Garry Kasparovworld champion at that time - in 1997 at the chess table, we have seen that the software program Watson proved to be the best player at the game JEOPARDY! in 2011. So, we can no longer deny that computers are marching on. Computers are better at searching, creating, and predicting than humans. Therefore, the significance of computer science for the legal practice will only increase.

Computer science does not only change the services of the legal profession, but also the society in which the legal profession operates. Van den Herik and Oerlemans concluded that the specialization of computer science is all-round, innovative and multidisciplinary. Moreover, it raises additional questions.

The most fascinating question that remains in the end is: do people see this development as progress? Possibly even more intriguing is the question: do computers hold the same view?

\subsection{Big Data and trends in law}

In his Valedictory Address at the Tilburg University (on January $29^{\text {th }}$, 2016) Van den Herik argues that Intuition is Programmable. [53] This is not only very important in chess, but also in law. The technical details will be suppressed here, but the statement in itself is sufficiently interesting to give it a thought. We would like to refer to the works of Big Data and in particular to the site www.ravellaw.com. 
A search machine is able to find the trends in a judge's verdicts and to distinguish peculiarities and also trends in the peculiarities. This implies that (1) human verdicts can be predicted and (2) lawyers have a means of influencing the judge's thought by anticipating on the trend the judge has shown so far.

Within ten years, there is more chess in the court room than there is law in the exciting chess world, where disputes are on secretly using machines during the game is nowadays usual.

In The Future of the Professions Richard and Daniel Susskind missed the opportunity to give their opinion on the profession of chess grandmasters. Imagine, the strongest computer program JONNY plays 400 Elo-points stronger than the human world champion. But still the grandmaster tournaments continue, see, e.g., the Tata-steel tournament in January 2016 in Wijk aan Zee, the Netherlands. The Susskinds re-iterated their earlier opinion on law and lawyers as given in [50] and state: "We predict that the legal world will change 'more radically over the next two decades' than 'over the last two centuries". So, there is still a competition between chess grandmasters and lawyers. The authors believe that the chess grandmasters are the toughest survivors since they really love the game.

\section{Conclusions}

In this paper we examined the use of AI in rendering verdicts by e-Court, the first online private court in the Netherlands. We discussed the legal decision making in the meaning of rendering default verdicts in debt collection proceedings.

We categorized the parameters required for rendering this type of verdicts, followed by a discussion of the Intelligent Systems in legal decision making. After analysis of the nature of the e-Court system, we had to conclude that the e-Court system makes only very limited use of the available Intelligent Systems in legal decision making. We introduced and discussed the rationale behind the cautious approach by e-Court. We then mentioned (1) three benefits of the use of the digital judge, (2) a major legal complication and (3) the manner in which the public courts process these verdicts.

The question arises whether we could argue that the robotic judge has developed from science fiction to a science fact, by coming into existence in this contemporary court house. Our answer to that question would be: "Yes and no".

The answer is "yes", because the verdicts in our case study are indeed generated solely as a result of the - selective, cost efficient and smart - use of AI, without any human reason or intervention involved whatsoever, once the Proceedings have started.

The answer is "no", because the type of cases this robotic judge can handle do not involve the weighing of arguments, the application of case law (jurisprudence) and a decision model in the case of doubt. In other words, the robotic judge has not yet come into its full power and existence from a technical point of view.

We will therefore not make the case that the robotic judge has come to its full Artificial Intelligent potential at e-Court. Nevertheless, he has indeed been brought to life, and he has successfully performed its tasks over the past four years. Our overall conclusion would therefore be that we are indeed witnessing the rise of the robotic judge in modern digital private court proceedings.

\section{References}

[1] R.A.J. Colenbrander, "Fragments of an investigation into the fundamental being of the office of public notary, especially according the current legislation (Fragmenten van een onderzoek naar het wezen van het notarisambt, in 't bijzonder volgens de tegenwoordige Nederlandsche wetgeving)", Nijkerk: J.J. Malga Jr. 1859, p. 130 e.v.

[2] A.W. Jongbloed, "Real execution in civil law, Contemplations on real execution under current and future law (Reële executie in het privaatrecht. Beschouwingen over reële executie naar geldend en wordend recht\}", (dissertation Nijmegen), Deventer: Kluwer 1987, p. 141-142.

[3] H.J. van den Herik, "Can Computers Judge Court Cases? (Kunnen Computers Rechtspreken?)" (inaugural address Leiden 21st June 1991), Arnhem: Gouda Quint 1991.

[4] H.W.R. Nakad-Weststrate and A.W. Jongbloed, "The digital Highway (De digitale Snelweg)", NL Journal for Litigation (Tijdschrift voor de Procespraktijk) 2010-2, p. 49-51.

[5] P. E. Ernste, "Court Proceedings at e-Court (Procederen bij e-Court)", NL Journal for Jurisprudence Civil Procedural Law 2010-3, p. 227232.

[6] J.C.A. Herstel, "Digital Justice (Digitale Rechtspraak)", Journal for Eastern Holland (Kijk op Oost-Nederland) 2010, p. 1.

[7] "InternetCourt is launched (Internetrechtbank van start)", the Daily Telegraph (De Telegraaf) 11 januari 2010.

[8] M. Klompers and M. van Reste, 'See you in eCourt?', Ars Aequi 2010, p. 301 e.v.

[9] A.W. Jongbloed, "From both angles: e-Court (Van twee kanten: e-Court)", "NL Judicial Magazine Themis (Rechtsgeleerd Magazijn Themis)" 2014-3, p. 111-116.

[10] R.C. Hartendorp, "From both angles: e-Court (Van twee kanten: e-Court)", "NL Judicial Magazine Themis (Rechtsgeleerd Magazijn Themis)" 2014-3, p. 117-121.

[11] M.L. Hendrikse and A.W. Jongbloed, "Civil Procedural law in Practice (Burgerlijk procesrecht praktisch belicht)", Deventer: Kluwer 2005., p. 106.

[12] A.W. Jongbloed, A.L.H. Ernes, "Rebalancing, Contemplations following the report "Balanced" (Herbalans. Beschouwingen naar aanleiding van het rapport Uitgebalanceerd)", Nijmegen: Ars Aequi Libri 2007, p.66. 
[13] "Ministry of Justice loses millions of euros with failed computerization (Justitie verspeelt opnieuw miljoenen euros met mislukte automatisering)" NOS 26 juni 2013, www.nos.nl.

[14] "Ministry of Justice burns millions of euros by failing ICT-project (Justitie verspilt miljoenen euro's door falend ICT-project)", Elsevier 26 juni 2013, www.elsevier.nl.

[15] G. Kaufmann-Kohler and T. Schultz (2004). Online Dispute Resolution: Challenges for Contemporary Justice, Kluwer LawInternational;

[16] H.J. van den Herik and D. Dimov, 'Towards Crowdsourced Online Dispute Resolution', in: S. Kierkegaard (red.), Law Across Nations: Governance, Policy \& Statutes, International Association of IT Lawyers (IAITL), 19 september 2011, p. 244-257, available at http://papers.ssrn.com/sol3/papers.cfm?abstract_id=1 93339;

[17] H.J. van den Herik and D. Dimov, 'Geschilbeslechting door crowdsourcing', Tijdschrift conflicthantering 2012, p. 19-22; D. Dimov en H.J. van den Herik, 'Използване на краудсоурсинг за разрешаване на спорове', Bulgarian Legal World Magazine 2012, www.legalworld.bg;

[18] H.J. van den Herik and D. Dimov, 'Een Crowdsourcing Model voor eBay', in: M. Kreijveld, Samen Slimmer. Hoe de 'wisdom of the crowds' onze samenleving zal veranderen, Den Haag: Stichting Toekomstbeeld der Techniek 2012, p. 28-30;

[19] J. Du Mortier, F. Robben and M. Taeymans, A Decade of Research at the Crossroads of Law and ICT, Gent: Larcier 2001;

[20] A.R. Lodder, 'Conflict resolution in Virtual worlds: General characteristics and the 2009 Dutch convictions on virtual theft', in: K. Cornelius and D Hermann (red.), Virtual worlds and criminality, Berlin: Springer 2011, p. 79-93;

[21] A.R. Lodder and J. Zeleznikow, 'Developing an Online Dispute Resolution Environment: Dialogue Tools and Negotiation Systems in a Three Step Model', Harvard Negotiation Law Review 2009-10, p. 287-338;

[22] A.R. Lodder and J. Zeleznikow, Enhanced dispute resolution through the use of information technology. Cambridge: Cambridge University Press 2010. D. Rainey, "Crowdsourced Online Dispute Resolution", Daniel Rainey's blog. 11 September 2009, http://danielrainey.blogspot.com/2009/09/crowdsourc ed-onlinedispute-resolution.html;

[23] C. Rule and C Nagarajan (2010) Leveraging the Wisdom of the Crowds: the Ebay Community Court and the Future of online Dispute Resolution. ACResolution Volume 2 (Issue 2), pp. 4-7;

[24] S. Sommers (2006), "On Racial Diversity and Group Decision Making: Identifying Multiple Effects of Racial Composition on Jury Deliberations. Journal of Personality and Social Psychology Volume 90 (Issue 4), 597-612;

[25] Surowiecki, J. (2005). The Wisdom of the Crowds. New York City, United States: Anchor Books, a division of Random House;

[26] N. Tideman (2006). Collective decisions and voting: the potential for public choice. Wey Court East, Farnham, Surrey, United Kingdom. Ashgate Publishing Limited;
[27] Peter Jackson, Introduction to Expert Systems, 1998; Cornelius T. Leondes, Fuzzy Logic and Expert Systems Applications (Neural Network Systems Techniques and Applications),1998; George F Luger, Artificial Intelligence Structure and Strategies for Complex Problem Saving, Addison Wesley, 2005

[28] M. Whitson, Cathy Wu, Pam Taylor, Using an artificial neural system to determine the knowledge based of an expert system, Proceedings of the 1990 ACM SIGSMALL/PC symposium on Small systems, pp.268-270, March 28-30, 1990, Crystal City, Virginia, USA.

[29] Joseph C. Gaiarratano, Gary Riley, "Expert Systems", PWS Publishing Co. Boston, MA, USA 1998; Mohammed Almulla, Tadeusz Szuba, Toward a computational model of collective intelligence and its IQ measure, Proceedings of the 1999 ACM symposium on Applied computing, p.2-7, February 28-March 02, 1999, San Antonio, Texas, USA.

[30] Rattapoom Tuchinda, Craig A. Knoblock, Agent wizard: building information agents by answering questions, Proceedings of the 9th international conference on Intelligent user interfaces, January 1316, 2004, Funchal, Madeira, Portugal.

[31] Cássia T. dos Santos , Fernando S. Osório, An intelligent and adaptive virtual environment and its application in distance learning, Proceedings of the working conference on Advanced visual interfaces, May 25-28, 2004, Gallipoli, Italy.

[32] Andreja Andrić, Vladan Devedić, Marko Andrejić, Translating a knowledge base into HTML, Knowledge-Based Systems, v.19 n.1, pp.92-101, March, 2006.

[33] Chakkrit Snae, Pupong Pongcharoen, Automatic rulebased expert system for English to Thai transcription, Proceedings of the third conference on IASTED International Conference: Advances in Computer Science and Technology, pp.342-347, April 02-04, 2007, Phuket, Thailand.

[34] Arijit Laha, RAP: a conceptual business intelligence framework, Proceedings of the 1st Bangalore Annual Compute Conference, January 18-20, 2008, Bangalore, India.

[35] Igor Wojnicki, Implementing general purpose applications with the rule-based approach, Proceedings of the 5th international conference on Rule-based reasoning, programming, and applications, July 19-21, 2011, Barcelona, Spain.

[36] P. Hayes (1977) In Defense of Logic. In Proceedings of the fifth International Joint Conference on Artificial Intelligence, pp. 559-565; P. Hayes (1978) Naive Physics I: Ontology for Liquids. In Formal Theories of the Commonsense World, eds. J. R. Hobbs and R. C. Moore. Norwood, N.J.

[37] P. Hayes (1979) The Logic of Frames. In Readings in Knowledge Representation, eds. R. Brachman and H. Levesque, 288-295; San Mateo, Calif.: Morgan Kaufmann.

[38] S. Fahlman, D. Touretsky and W. van Roggen, (1981). Cancellation in a Parallel Semantic Network In Proceedings of the Seventh International Joint Conference on Artificial Intelligence, pp. 257-263.

[39] J. Doyle and R. Patil (1989). Two Dogmas of Knowledge Representation, Technical Memo, 387B, Laboratory for Computer Science, Massachusetts Institute of Technology. 
[40] W. Hamscher (1991) Modeling Digital Circuits for Troubleshooting. Artificial Intelligence 51: pp. 223272.

[41] R. Davis, H. Schrobe, P. Szolovits (1993), What is a Knowledge Representation?, A.I. Magazine, Vol. 14, nr. 1.

[42] Baharum Baharudin, Lam Hong Lee, Khairullah Khan: A Review of Machine Learning Algorithms for Text-Documents Classification Journal of Advances in Information Technology, Vol 1, No 1 (2010), pp. 4-20, 2010.

[43] Juergen Schmidhuber: Deep Learning in Neural Networks: An Overview, Neural Networks, Vol 61, pp. 85-117, 2015.

[44] Yann LeCun,, Yoshua Bengio, Geoffrey Hinton: Deep learning, Nature, Vol. 521, pp. 436-444, 2015.

[45] "Case-Based Reasoning Tools from Shells to ObjectOriented Frameworks", Abdrabou, E. A. M. \& Salem, A. B. Advanced Studies in Software and Knowledge Engineering- Supplement to the International Journal "INFORMATION TECHNOLOGIES \& KNOWLEDGE" Ed. Krassimir Markov, Krassimira Ivanova, Ilia Mitov Sofia: Institute of Information Theories and Applications FOI ITHEA, pp. 37$44,2008$.

[46] "Ideas of Case-Based Reasoning for Keyframe Technique", Hans-Dieter, Abdel- Badea Salem, Bassant Mohamrd El Bagoury, Proceedings of the XVIth International Workshop on the Concurrency Specification and Programming, CS \& $\mathrm{P}$ 2007,Logow, Warsa, Poland, pp. 100-106, 27-29 September 2007.

[47] "Case Based Reasoning Technology for Medical Diagnosis", Abdel-Badeeh M. Salem, Proceedings of World Academy of Science, Engineering And Technology, CESSE, Venice, Italy, Volume 25, pp. 913, November 2007.

[48] M. GR. Voskoglou, A. - B. M. SALEM, "AnalogyBased and Case-Based Reasoning: Two Sides of the Same Coin", International Journal of Applications of Fuzzy Sets and Artificial Intelligence, Vol. 4, pp. 551, 2014.

[49] 'The Future of the Professions', R. Susskind, London: Oxford University Press, 2015.

[50] 'The End of Lawyers?', R.Susskind and D. Susskind, London: Oxford University Press, 2008.

[51] Jordan Furlong, Book Review: The End of Lawyers, pubslihed on www.law21.ca, February $10^{\text {th }}, 2009$

[52] Jaap van den Herik and Jan Jaap Oerlemans: Lawyers follow chess players, in Blueprints of the future, today's science is tomorrow's world, to the Evening of Science and Society, Leiden 2014.

[53] "Machines are easier to educate than humans", Folkert Jensma in the Dutch newspaper NRC Weekend O\&D, p.9, January 2-3, 2016. 